Arch. Dis. Childh., 1963, 38, 260.

\title{
OBSERVATIONS ON PERCUTANEOUS RENAL BIOPSY IN CHILDREN
}

\author{
BY
}

\author{
RICHARD H. R. WHITE* \\ From The Hospital for Sick Children, Great Ormond Street, London, and \\ the Department of Paediatrics, Makerere University College Medical School, Kampala, Uganda
}

(RECEIVED FOR PUBLICATION OCTOBER 15, 1962)

The first serious attempt to develop the technique of percutaneous renal biopsy was made by Iversen and Brun (1951), although its use had previously been reported by Pérez Ara (1950). Alwall (1952) abandoned it following a fatality in 1944 but did not report his findings until eight years later. Kark and Muehrcke (1954) devised a more satisfactory biopsy technique in the prone position, using Franklin's modification of the VimSilverman liver biopsy needle (Kark, Muehrcke, Pollak, Pirani and Kiefer, 1958) and succeeded 48 times in their first 50 attempts. It was not long before the practical and academic potentialities of percutaneous renal biopsy in childhood were realized; Galán and Masó (1957) first reported its use in their study of nephrotic children.

In the same year Vernier and his colleagues (Farquhar, Vernier and Good, 1957) published the first of a series of papers concerning renal biopsy in children. They have now performed over 250 biopsies, with 'no deaths which could be attributed to the biopsy procedure' (Vernier, 1960), and Dodge, Daeschner, Brennan, Rosenberg, Travis and Hopps (1962) have recently added a further 205 biopsies. The use of renal biopsy in children has so far received little prominence in reports from Great Britain.

This paper records observations on the first hundred renal biopsies, performed personally upon children, using a technique based upon that of Kark and Muehrcke (1954). The main purpose of the paper is to indicate the practicability of the procedure in children, and special reference is made to technical details which, it is believed, may contribute towards lessening the risks of failure and of danger to the patient. It is not intended to give a detailed pathological analysis, for the material obtained

\footnotetext{
* Present address: Department of Paediatrics, Guy's Hospital, London S.E.1.
}

falls into several categories and will be published separately. However, the adequacy of specimens for histological interpretation, based on glomerular yields, will be discussed. The applications of percutaneous renal biopsy have been fully discussed elsewhere (Kark et al., 1958; Vernier, 1960; Pirani and Muehrcke, 1960; Ciba Foundation Symposium on Renal Biopsy, 1961).

\section{Selection and Preparation of Patients}

Renal biopsy should be performed only in hospital, where careful post-operative observation is possible. A plain abdominal radiograph is first obtained, to demonstrate the presence of two kidneys, in approximately normal positions. A Senokot enema, which contains standardized senna in isotonic saline, is given two hours before, and has been found to give excellent clearance of unwanted intestinal gas shadows. Satisfactory films have been obtained in most Caucasian children but, in many African children, the demonstration of renal outlines has been found disappointing, possibly owing to lack of perirenal fat. Intravenous pyelography may, therefore, be necessary; a single ten-minute film is usually sufficient.

A known bleeding tendency is an absolute contraindication to percutaneous renal biopsy but, in the absence of such a history, estimation of the bleeding time and prothrombin index will rule out important abnormalities. In doubtful cases the blood coagulation mechanism should be fully investigated. Before biopsy it is advisable to ensure that compatible blood is available for transfusion. In seriously ill children, or those with acute oliguric renal failure, with a rapidly rising blood urea, biopsy should be postponed until the patient's condition warrants it. Anaemia may increase the risk of biopsy if postoperative bleeding occurs. Renal tumours, hydro- 
nephrosis and perirenal abscess are further contraindications (Pirani and Muehrcke, 1960).

\section{Biopsy Technique}

Most of the early biopsies in this series were performed under general anaesthesia, the kidneys' movements on respiration being controlled by means of intravenous succinyl choline. Anaesthesia was induced with the patient supine and biopsy was performed in the prone position. At present local analgesia and sedation are used almost exclusively, an exception being made only when sedation is ineffective and the child shows extreme apprehension or inability to co-operate. The best premedication consists of pethidine hydrochloride, $2 \mathrm{mg} . / \mathrm{kg}$., chlorpromazine hydrochloride, $1 \mathrm{mg} . / \mathrm{kg}$., and promethazine hydrochloride, $1 \mathrm{mg}$./ $/ \mathrm{kg}$. body weight, given by intramuscular injection one hour before biopsy. Paraldehyde has also been used in young African children with protein-calorie malnutrition, in whom the action of pethidine is less predictable than usual. A dose of $0.4 \mathrm{ml} . / \mathrm{kg}$. body weight is given intramuscularly one hour before biopsy. A simple explanation of the procedure is first given to most children over 4 years old, and a ward nurse, whom the child knows, accompanies him and constantly endeavours to reassure him throughout the procedure.

The patient is placed prone on a couch or operating table and a sandbag is inserted beneath the abdomen, or the kidney bridge is raised. After cleaning the skin, the landmarks are palpated. Initially radiographic localization of the lower pole of the kidney was employed and landmarks were meticulously outlined with dye on the patient's skin as described by Muehrcke, Kark and Pirani (1955). However, analysis of the first 35 biopsies revealed that however laborious the preparation the needle was invariably inserted through the skin just below the angle formed by the intersection of the lowest palpable rib and the lateral border of the sacrospinalis muscle (Fig. 1). The relation between supine radiographic location of the kidney and its actual position in a child lying prone with a sandbag under the abdomen is uncertain, and exploration with a fine needle, which is an essential preliminary manoeuvre, gives more precise localization.

The skin, subcutaneous tissue and muscle are infiltrated with $2 \%$ procaine, unless general anaesthesia is used. If this is done with care and patience, the child will experience very little discomfort and, given adequate sedation and sufficient time for completion of analgesia, the biopsy procedure will be accepted without resistance. During infiltration, very young children may resist, and it is therefore

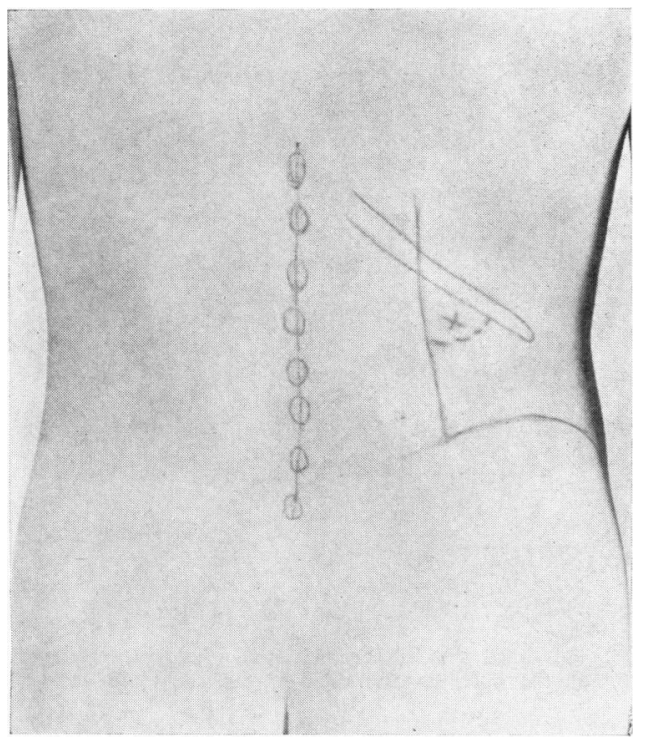

FIG. 1.-Surface markings for renal biopsy. The needle is inserted at $\mathrm{X}$. See text for description.

wise to employ an assistant who, by placing the hands gently but firmly upon the buttocks and behind the knees, can restrict unexpected sudden movements.

The next step is to locate the kidney by means of a long No. 20 needle, which is introduced parallel with the vertebral spines and in a slightly cephalad direction, until the kidney is reached. With experience the muscular and fascial layers of the posterior abdominal wall and the firmness of kidney tissue can generally be felt, but the renal capsule is not often distinguishable unless pathologically thickened. The respiratory movement of the kidney causes an oscillation of the exploring needle, which can be amplified by deep breathing in a co-operative child (Muehrcke et al., 1955). The amplitude of the swing, however, is occasionally misleading. The renal excursion may be very small, especially when general anaesthesia and muscle relaxants are used, and yet a wide oscillation may be observed when the tip of the needle is in perirenal fat. If, at the first attempt, the kidney is not located, the needle may be withdrawn and redirected slightly medially or superiorly, until the kidney is found.

Three further movements of the exploring needle may also assist in the kidney's identification (Kark et al., 1958). The needle may transmit arterial pulsations and may, occasionally, also show rotation around its long axis. These two movements, superimposed upon the respiratory swing, indicate that the needle has entered the kidney. The third 


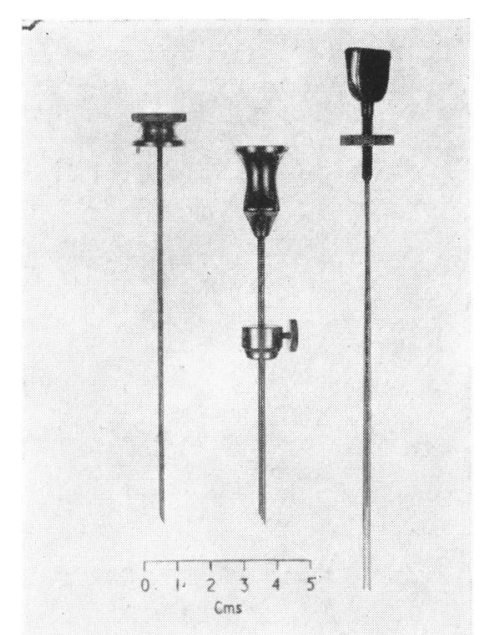

FIG. 2.-Modified Vim-Silverman biopsy needle with an adjustable stop on the outer needle and a variable-length inner needle.

movement is sometimes seen when the tip of the needle lies very close to the kidney but has not punctured the capsule. During inspiration the needle does not swing evenly but appears to be 'taken up' by the impact of the kidney and, as it begins to move, a distinct flick is seen. To complete the procedure very little adjustment of the needle's position is needed. It is wiser not to insert the biopsy needle until the kidney has been identified with reasonable certainty, and inexplicable failure must sometimes be accepted. Before the exploring needle is withdrawn, a short length of capillary rubber tubing mounted transversely on its shaft is pushed down against the skin, to facilitate measurement of the skin-to-kidney depth.

For the biopsy, a modified Vim-Silverman biopsy needle is used (Fig. 2). It has an adjustable stop on the shaft of the outer needle and a device for altering the depth of insertion of the cutting prongs through a range of $1 \cdot 5-2 \cdot 5 \mathrm{~cm}$. (White, 1962). A setting of $1.5 \mathrm{~cm}$. is used in infants and $2 \mathrm{~cm}$. in older children. Since the principal aim is to obtain cortical tissue, longer settings are unnecessary. The stop on the outer needle is first secured at a distance from the bevel equal to the skin-to-kidney depth plus the selected setting of the cutting prongs. Through a small stab incision, the needle with stilette in place is introduced along the track of the exploring needle until it is thought to have reached the kidney, as indicated by its movements and by the firmness of the tissue. The renal capsule is best pierced by a rapid jab; slow advancement may sometimes cause displacement of the kidney and penetration may not occur. A satisfactory biopsy will not be obtained unless the renal capsule has first been breached by the outer needle, but too deep penetration of the kidney substance, on the other hand, will limit the thickness of available cortical tissue. The stilette is next removed and the inner needle gently inserted until resistance is met. Experience has shown that if the inner needle can be inserted to its full depth without meeting resistance, the outer needle has not penetrated the renal capsule. The feel of kidney tissue encountered by the exploring and outer biopsy needles is not always definite but, with the inner biopsy needle, it is quite unmistakable, and is the most reliable indication of the kidney's identity. If resistance is not at first felt, the stilette should be replaced and the outer needle inserted a little further or redirected.

The biopsy is completed in three rapid movements. First, the outer needle is held by the left hand while with the right hand the inner needle is inserted until the adjustable 'runner' is arrested by the hub of the outer needle. The position of the inner needle is then manually fixed in relation to the child while the outer needle is advanced until the safety stop reaches the skin. Finally, the whole instrument is withdrawn. The second movement closes the cutting prongs, dividing the specimen at its attachment. In advancing the outer needle considerable resistance is sometimes met, and the inexperienced operator will notice that the right hand tends to exert an involuntary counter-traction on the inner needle. This must be corrected if good specimens are to be obtained. During these three movements the child should, if possible, hold his breath but if he is unable to co-operate each movement may be made during the passive expiratory phase, pausing during inspiration. Except during these movements, it is never necessary to grasp the needle tightly. With effective sedation and local analgesia, the child remains asleep during biopsy. The respiratory excursions are usually small and, provided that movements of the needle are executed swiftly and skilfully, the risk of capsular tear is very slight. In the occasional child who cries, expiration is prolonged, and this is of advantage to the operator. It is the author's practice to take a second specimen from a different part of the kidney by aiming the biopsy needle in a more cephalad direction through the same incision.

After operation, the patient remains resting until the following morning and the pulse, blood pressure and urine are examined at intervals for evidence of haemorrhage. Abundant fluid should be drunk to minimize the risk of blood clotting within the renal pelvis and causing colic. 


\section{Processing of Specimens}

The specimen is carefully removed from the needle and straightened out upon a glass slide to prevent it from curling during fixation. If required, $1-\mathrm{mm}$. cubes may be cut off and processed for electron microscopy. The remainder is placed in Susa fixative and the specimens are embedded in paraffin, serially cut at $2-4 \mu$ thickness and stained with haematoxylin and eosin, and by the periodic acid-Schiff method which enables the glomerular capillary basement membrane to be studied (Hutt, de Wardener and Sommers, 1959). Comparison of Susa-fixed and formalin-fixed kidney material, obtained from the same patient, has repeatedly shown that for these stains the former is superior.

\section{Material}

This analysis includes the first hundred personal biopsy attempts, performed upon 80 children, of whom 23 were European, 55 African, and two Asian. There were 46 boys and 34 girls, with an age range of 26 days to 15 years (Table 1). The right kidney was investigated 56 and the left 44 times. General anaesthesia was employed 39 and local analgesia 61 times.

\section{Results}

Specimens measured 5-27 mm. in length, with an average of $15 \mathrm{~mm}$. Two specimens were obtained from all but three of the patients in whom biopsy
TABLE 1

RELATION OF BIOPSY RESULTS TO AGE OF CHILDREN

\begin{tabular}{c|c|c|c|c|c|c}
\hline Age & $\begin{array}{c}\text { No. } \\
\text { of } \\
\text { Patients }\end{array}$ & $\begin{array}{c}\text { No. of } \\
\text { Biopsy } \\
\text { Attempts }\end{array}$ & \multicolumn{2}{|c|}{ Failures } & \multicolumn{2}{|c|}{ Glomerular Counts } \\
\cline { 4 - 6 } & No. & $\%$ & Range & Average \\
\hline $\begin{array}{c}\text { mths } \\
\text { mths }\end{array}$ & 4 & 4 & 1 & 25 & $34-88$ & 65 \\
$\begin{array}{c}12-23 \\
\text { mths }\end{array}$ & 14 & 14 & 1 & $7 \cdot 1$ & $32-163$ & 85 \\
$\begin{array}{c}2-5 \\
\text { yrs }\end{array}$ & 35 & 45 & $4 *$ & $8 \cdot 9$ & $10-204$ & 67 \\
$\begin{array}{c}6-9 \\
\text { yrs }\end{array}$ & 18 & 27 & $2 \dagger$ & $7 \cdot 4$ & $6-107$ & 50 \\
$\begin{array}{c}10-15 \\
\text { yrs }\end{array}$ & 9 & 10 & 1 & 10 & $12-82$ & 37 \\
Total .. & 80 & 100 & 9 & 9 & $6-204$ & 63 \\
\hline
\end{tabular}

* One failure due to specimen containing no glomeruli; later successfully repeated.

$\dagger$ Both due to defective needle; successfully repeated. See Table 2.

was successful, and the number of glomeruli counted per biopsy (i.e. in most instances the total of two specimens) ranged from six to 204 , with an average of 63 .

There were nine instances of complete failure or inadequate biopsy, details of which are given in Table 2. It will be seen that in three of the earlier biopsies the kidney was identified with reasonable certainty by its respiratory movement and tissue firmness, and failure was attributable to incorrect bevelling of the cutting prongs of the prototype

TABLE 2

ANALYSIS OF FAILURES

\begin{tabular}{|c|c|c|c|c|c|c|c|c|c|}
\hline \multirow[t]{2}{*}{$\begin{array}{l}\text { Biopsy } \\
\text { Number }\end{array}$} & \multirow[t]{2}{*}{$\begin{array}{l}\text { Age } \\
\text { (yrs) }\end{array}$} & \multirow[t]{2}{*}{$\begin{array}{c}\text { Clinical } \\
\text { Diagnosis }\end{array}$} & \multirow[t]{2}{*}{$\begin{array}{l}\text { L. or R. } \\
\text { Kidney }\end{array}$} & \multirow[t]{2}{*}{$\begin{array}{l}\text { Anaes- } \\
\text { thesia }\end{array}$} & \multirow[t]{2}{*}{$\begin{array}{l}\text { Condition } \\
\text { of Needle }\end{array}$} & \multicolumn{2}{|c|}{$\begin{array}{l}\text { Kidney's } \\
\text { Identi- } \\
\text { fication }\end{array}$} & \multirow[t]{2}{*}{$\begin{array}{c}\text { Biopsy } \\
\text { Repeated }\end{array}$} & \multirow[t]{2}{*}{ Remarks } \\
\hline & & & & & & Swing & $\begin{array}{c}\text { Firm- } \\
\text { ness }\end{array}$ & & \\
\hline 8 & $8 \frac{1}{2}$ & Nephrotic syndrome & $\mathbf{R}$. & G.A. & Defective & + & + & Successful & Performed at same session \\
\hline 9 & 6 & Proteinuria & $\mathbf{R}$. & G.A. & Defective & + & + & Successful & needle prototypes \\
\hline 14 & 4 & Nephrotic syndrome & L. & G.A. & Sharp & + & + & Successful & No glomeruli in specimens \\
\hline 17 & 11 & $\begin{array}{l}\text { Hypercalcaemia; } \\
\text { ? nephrocalcinosis }\end{array}$ & $\mathbf{R}$. & G.A. & Unsharpened & + & + & No & $\begin{array}{l}\text { Due to bluntness of inner } \\
\text { needle }\end{array}$ \\
\hline 21 & $11 \mathrm{mths}$ & $\begin{array}{l}\text { Failure to thrive; } \\
\text { ? chronic pyelo- } \\
\text { nephritis }\end{array}$ & L. & G.A. & Sharp & - & - & No & $\begin{array}{l}17 \text { lb. ( } 7 \cdot 7 \text { kg.) infant; } \\
\text { surgical biopsy showed } \\
\text { small kidneys with } \\
\text { chronic pyelonephritis }\end{array}$ \\
\hline 23 & $23 \mathrm{mths}$ & $\begin{array}{l}\text { Failure to thrive; } \\
\text { ? chronic pyelo- } \\
\text { nephritis }\end{array}$ & L. & G.A. & Sharp & + & - & No & $\begin{array}{l}13 \mathrm{lb} .(5 \cdot 9 \mathrm{~kg} .) \text { child; pro- } \\
\text { bably contracted kidneys }\end{array}$ \\
\hline 28 & 5 & Nephrotic syndrome & L. & G.A. & Sharp & - & - & No & Failure unexplained \\
\hline 31 & 5 & Nephrotic syndrome & L. & G.A. & Sharp & + & + & No & $\begin{array}{l}\text { Splenomegaly; kidney's } \\
\text { identity mistaken, splenic } \\
\text { tissue obtained }\end{array}$ \\
\hline 46 & 4 & Kwashiorkor & $\mathbf{R}$. & L.A. & Sharp & - & - & No & Failure unexplained \\
\hline
\end{tabular}


instrument (White, 1962). In two of the patients a further attempt was permitted and succeeded on both occasions. In another child biopsy was apparently successful but neither specimen contained any glomeruli; a second biopsy contained 37, however. Splenic tissue was once obtained from a child with moderate splenomegaly, on attempted biopsy of the left kidney. In the remaining four failures the kidney was not located by the exploring needle, in spite of radiographic definition. General anaesthesia was used in three of these unexplained failures and local analgesia in one.

Complications. Transient gross haematuria occurred 13 times and caused renal colic on one occasion. Only one child complained of pain in the loin after operation but, on questioning, most older children admitted experiencing slight aching over the biopsy site, although few retained any memory of the procedure. One African child with nephrosis became shocked after biopsy under general anaesthesia but recovered following a small blood transfusion. There was no haematuria but the pre-operative haemoglobin was only $8.9 \mathrm{~g} . / 100 \mathrm{ml}$., owing to hookworm infection.

Two African children died within 24 hours of biopsy, one as a result of the biopsy. The first, a 5-year-old nephrotic with a blood urea of $83 \mathrm{mg}$./ $100 \mathrm{ml}$. but no hypertension, suffered cardiac arrest at the conclusion of biopsy under general anaesthesia. At thoracotomy a small pericardial effusion was discovered. The heart was restarted following massage and intracardiac injection of $2 \mathrm{ml}$. of $1: 10,000$ adrenaline, but the child never regained consciousness and died 17 hours later. There was neither haematuria nor clinical evidence of perirenal haematoma. The body was swiftly removed from hospital by the father, so that no autopsy was possible. This death must be accepted as due to the performance of renal biopsy under general anaesthesia, although the biopsy showed chronic glomerulonephritis with advanced sclerosis of nearly all 72 glomeruli present.

The second, a baby aged 26 days weighing $3 \cdot 2 \mathrm{~kg}$., was admitted with gross pitting oedema, proteinuria and hypo-albuminaemia, and an inflamed umbilical stump. The blood urea was $98 \mathrm{mg}$. $/ 100 \mathrm{ml}$. and the antistreptolysin titre was greater than 333 units per $\mathrm{ml}$. A diagnosis of septicaemia with either inferior vena caval thrombosis or congenital nephrosis was made and, in spite of antibiotic therapy, his condition deteriorated. Since both kidneys were easily palpable, it was decided to attempt renal biopsy before considering introducing steroid therapy. Under local analgesia two small specimens were obtained from the right kidney. After operation there was no haematuria but the infant's condition continued to deteriorate and he died 23 hours later. At autopsy two fine needle tracks were seen to pass through the infero-lateral part of the renal cortex and $2 \mathrm{ml}$. of blood were found beneath the renal capsule. The abdominal viscera were intact and there was no evidence of trauma. There were multiple abscesses in the umbilical vein, liver, heart muscle and lungs which also contained extensive haemorrhages.

Some of the 72 glomeruli present in the biopsy showed the features of immaturity seen in the 'nephrogenic zone' of the neonatal kidney (Potter, 1952), but most of the mature glomerular tufts showed diffuse cellular proliferation and occasional polymorphonuclear leucocytes. Several tubules and a few capsular spaces contained red blood cells. These changes were confirmed at autopsy and it is believed that the infant had suffered from acute, post-streptococcal glomerulonephritis, although the immediate cause of death was pulmonary haemorrhage associated with septicaemia.

\section{Discussion}

To be acceptable, a biopsy procedure must be comparatively free from risk. Assessment of mortality is difficult because a number of fatal accidents may remain unpublished (Sherlock, 1958). In the Ciba Foundation Symposium on Renal Biopsy (1961) contributors from 15 medical centres reported experiencing no fatalities in 5,120 biopsies, but four unpublished deaths from other centres were cited. A questionnaire circulated by Slotkin and Madsen (1962), and answered by 70 urologists, recently revealed four unpublished deaths among 5,000 renal biopsies. These were attributable to haemorrhage in already seriously ill patients, as was the death reported by Zelman (1954) who performed simultaneous liver and renal biopsies upon a uraemic man. Such deaths reflect faulty selection of patients rather than the true mortality from the procedure. The second death reported in the present series, while not directly attributable to renal biopsy, nevertheless illustrates the need for careful preliminary assessment of the patient's fitness.

Unexplained death may rarely occur in a patient who is considered fit for biopsy (Reubi, 1954). In this series the death from cardiac arrest was probably related to the use of general anaesthesia and, although not a full explanation, it is suggested that the child's haemodynamics may have been considerably altered as a result of compression of the major abdominal blood vessels by the sandbag, facilitated by the use of a muscle relaxant, in the 
presence of a pericardial effusion. The literature contains reference to 17 fatalities (including the one in the present series attributable to biopsy), amongst well over 10,000 biopsies (Ciba Foundation Symposium on Renal Biopsy, 1961; Slotkin and Madsen, 1962; Dodge et al., 1962), giving an estimated mortality of $0.17 \%$. Allowing for other unpublished deaths, this figure is probably optimistic but nevertheless compares favourably with that of liver biopsy (Sherlock, 1958).

Reference to Table 2 reveals that three of the four unexplained failures were associated with the use of general anaesthesia. Muscle relaxants, while giving complete respiratory control over the kidneys' movements, also paralyse the abdominal and diaphragmatic musculature and it is believed that in these circumstances the prone position, coupled with sandbag compression, may cause upward displacement and increased mobility of the kidneys, thus impeding their identification. The prone position, in which much of the weight of the trunk is supported by the anterior chest wall, is not ideal for artificial pulmonary ventilation, and the possible risk of major vascular compression, associated with the use of muscle relaxants, cannot be ruled out. However, in commenting on the higher failure rate associated with general anaesthesia, it must be pointed out that in this series the routine use of sedation and local analgesia was adopted only after the 39th biopsy, 38 of which, including all eight failures, had been performed under general anaesthesia. The lower failure rate observed in biopsies under local analgesia is thus associated with greater technical experience. Nevertheless, the use of sedation and local analgesia has, in the author's experience, been associated with diminished technical difficulty and parental anxiety and greater convenience.

The overall failure rate in the present series is $9 \%$, but if the three failures which were subsequently repeated with success are excluded the failure rate becomes $6 \cdot 2 \%$. By the current technique, using local analgesia, it is less than $2 \%$ (one failure out of 61 attempted biopsies). These figures compare favourably with those of other workers. Parrish and Howe (1955) obtained adequate tissue for histological interpretation in only 100 out of 169 attempts (59\%). Phillippi, Robinson and Langelier (1961) succeeded in $70 \%$ of young adults. Kark et al. (1958), reviewing 500 attempted biopsies, of which only 19 were in children under 12 years, reported complete failure in $7 \%$ of their attempts, and inadequate tissue in a further $13 \%$. Their glomerular yields ranged from 0 to 44 , averaging 12 , and they regard as adequate a specimen containing five or more glomeruli. In children, Dodge et al. (1962) have achieved $92 \%$ success, with glomerular yields of 15 to 30 per specimen. Vernier, Farquhar, Brunson and Good (1958) achieved 70\% success in children over 2 years old, using as their criterion of adequacy a minimum of 10 glomeruli, and most of their specimens contained 15 to 30 glomeruli. They expressed a preference for surgical biopsy in children under 2 years because of their high failure rate with needle biopsy. In the present series, however, 18 biopsies were attempted in children under 2 years (Table 1), giving high glomerular yields and only two failures (11\%).

Although splenic tissue was accidentally obtained from a child with moderate splenomegaly, the risks of failure or complication arising from biopsy of the left kidney in children without splenomegaly do not seem to be greater than those of right renal biopsy. Muehrcke et al. (1955) preferred to avoid the left kidney because of the possibility of injuring the spleen or adjacent blood vessels but Phillippi et al. (1961) selected it almost invariably. Such refinements as renal radiography by means of retropneumoperitoneum (Fiaschi, Ercoli and Torsoli, 1953), estimation of the kidney's depth by an ultrasonic flaw detector (Berlyne, 1961), and performance of needle biopsy through a surgical incision after digital palpation of the kidney (Morales, Hamilton, Brown and Hotchkiss, 1961), complicate the procedure and do not significantly reduce the incidence of failures.

Kark et al. (1958) stated that 'In our opinion, operators should not do percutaneous renal biopsies on infants and children until they have had considerable experience with adults.' This opinion can no longer remain unchallenged, and it is hoped that the results reported here will provide encouragement to others who intend applying renal biopsy in children.

\section{Summary}

Observations on 100 consecutive percutaneous renal biopsies performed personally on children are recorded. Of the 80 children whose kidneys were examined, 18 were under 2 years of age.

The technique, with simple modifications, is described, and a comparison of anaesthetic methods is made, favouring the use of sedation and local analgesia.

The overall failure rate in this series is $9 \%$, or $6.2 \%$ if three patients in whom failure was followed by successful repeat biopsy are excluded. With sedation and local analgesia it is less than $2 \%$. These results are compared with those of other workers.

The risks of renal biopsy are discussed and two 
deaths are reported, one unrelated to biopsy, the other associated with the use of general anaesthesia.

I am grateful to the physicians of The Hospital for Sick Children, Great Ormond Street, London, and Mulago Hospital, Kampala, Uganda, for their encouragement. This paper is published with the authority of the Chief Medical Officer, Ministry of Health, Uganda. Fig. 2 is reproduced by courtesy of the Lancet. The Senokot enemas were kindly supplied by Westminster Laboratories Ltd., London.

\section{REFERENCES}

Alwall, N. (1952). Aspiration biopsy of the kidney. Acta med. scand., $143,430$.

Berlyne, G. M. (1961). Ultrasonics in renal biopsy: An aid to determination of kidney position. Lancet, 2, 750.

Ciba Foundation Symposium on Renal Biopsy-Clinical and Pathological Significance (1961). Ed. G. E. W. Wolstenholme and M. P. Cameron. Churchill, London.

Dodge, W. F., Daeschner, C. W., Jr., Brennan, J. C., Rosenberg, (1962). Percutaneous $30,287$.

Farquhar, M. G., Vernier, R. L. and Good, R. A. (1957). An electron microscope study of the glomerulus in nephrosis, glomerulonephritis and lupus erythematosus. $J$. exp. Med., glomerulo 649 .

Fiaschi, E., Ercoli, G. and Torsoli, A. (1953). La biopsia renale mediante agopuntura transcutanea; Rilievi anatomo-clinici. Minerva med., 44, Parte Scientifica, pt. 2, 1851. Galán, E. and Masó, C. (1957). Needle biopsy in children with
nephrosis. Pediatrics, 20,610.

Hutt, M S. R., de Wardener, H. and Sommers, S. C. (1959). Renal biopsy: Some observations on the histology of the glomerulus. J. clin. Path., 12, 577.
Iversen, P. and Brun, C. (1951). Aspiration biopsy of the kidney. Amer. J. Med., 11, 324.

Kark, R. M. and Muehrcke, R. C. (1954). Biopsy of kidney in prone position. Lancet, 1, 1047.

-, Pollak, V. E., Pirani, C. L. and Kiefer, J. H. (1958), An analysis of five hundred percutaneous renal biopsies. A.M.A. Arch. intern. Med., 101, 439.

Morales, P., Hamilton, K., Brown, J. and Hotchkiss, R. S. (1961). Open renal biopsy. J. Urol. (Baltimore), 86, 501.

Muehrcke, R. C., Kark, R. M. and Pirani, C. L. (1955). Technique of percutaneous renal biopsy in the prone position. ibid., $74,267$.

Parrish, A. E. and Howe, J. S. (1955). Kidney biopsy. A.M.A. Arch. intern. Med., 96, 712.

Pérez Ara, A. (1950). La biopsia punturel del riñón no megálico. Consideraciones generales $\mathrm{y}$ aportación de un nuevo método. Bol. Liga Cáncer (Habana), 25, 121.

Phillippi, P. J., Robinson, R. R. and Langelier, P. R. (1961). Percutaneous renal biopsy. Observations with specific reference to asymptomatic proteinuria. A.M.A. Arch. intern. Med., 108, 739.

Pirani, C. L. and Muehrcke, R. C. (1960). Renal biopsy. In Recent Advances in Clinical Pathology, ed. S. C. Dyke, p. 357. Churchill, London.

Potter, E. L. (1952). Pathology of the Fetus and the Newborn, p. 356. Year Book Publishers, Chicago.

Reubi, F. (1954). La ponction-biopsie du rein. Helv. chir. Acta, $21,128$.

Sherlock, S. P. V. (1958). Diseases of the Liver and Biliary System, 2nd ed., p. 64 . Blackwell, Oxford.

Slotkin, E. A. and Madsen, P. O. (1962). Complications of renal biopsy: Incidence in 5,000 reported cases. J. Urol. (Baltimore), biopsy:

Vernier, R. L. (1960). Kidney biopsy in the study of renal disease. Pediat. Clin. N. Amer., 7, 353.

, Farquhar, M. G., Brunson, J. G. and Good, R. A. (1958). Chronic renal disease in children. A.M.A. Amer. J. Dis. Child., 96, 306.

White, R. H. R. (1962). A modified Silverman biopsy needle for use in children. Lancet, 1, 673.

Zelman, S. (1954). Fatal hemorrhage following needle biopsy in uremia. J. Amer. med. Ass., 154, 997. 